The Egyptian Journal of Hospital Medicine (April 2013) Vol. 51, Page 264 - 274

\title{
CARDIOMETABOLIC PROTECTIVE EFFECTS OF SOME MEDICINAL PLANTS IN DIABETIC ALBINO RATS
}

Waleed S. Mohamed, ${ }^{1}$ Ashraf M. Mostafa, ${ }^{2}$ Abdel Hamid A. Serwah, ${ }^{3}$

And Khaled M. Mohamed ${ }^{4}$

Internal Medicine Department ${ }^{1,3}$, Anatomy and Histology Department ${ }^{2}$, College of Medicine, Taif University, KSA; Pharmacognosy Department ${ }^{4}$, College of Pharmacy, Taif University, KSA.

Author of Correspondence: Waleed S. Mohamed, Internal Medicine Department, College of Medicine, Taif University.E-mail: wsmohamed1@yahoo.com Mobile: 00966/553420886

\begin{abstract}
Background and aim of the study: DM represents an important independent risk factor for the development of and mortality from coronary heart disease (CHD), increasing the risk by 2 to 4 times. According to WHO data, more than $75 \%$ of patients with DM die due to vascular accidents. This study investigated the effects of some plants used in Saudi Arabia and some other Arab countries as antidiabetic agents and explores its metabolic effects.

Material and Methods: One hundred fifty adult male Albino Rats were divided into six experimental groups each consist of twenty five rats. The first group was considered as a control group. The rest of groups were affected by induction of experimental diabetes by subcutaneous injection of Alloxan. The second group consisted of diabetic rats without any treatment. The third group was treated by the aqueous extract of mixture contains Foenugreek, Nigella sativa and Termis seeds. The fourth group was treated with the aqueous extract of Nigella sativa seeds $(100 \mathrm{mg} / \mathrm{kg}$ of body weight), while the fifth group was treated with the aqueous extract of Foenugreek seeds (100 mg / $\mathrm{kg}$ of body weight). The sixth one was treated with the aqueous extract of Termis seeds $(100 \mathrm{mg} / \mathrm{kg}$ body weight). After four weeks of treatment, different biochemical parameters were performed including estimation of blood sugar level and serum insulin level. Pancreatic and liver samples were obtained and processed for microscopic and quantitative evaluation after staining the prepared sections with both Heamatoxylin and Eosin as well as special stain for demonstration of the different pancreatic cells in the Islet of the Langerhans.

Results: The usage of the mixture or each plant alone corrected the glucose level and insulin level. Microscopically there was definite decrease in the number and diameter of beta pancreatic cells in the diabetic group while the other pancreatic cells were not affected (alpha and delta cells). The use of medicinal plants in the different groups of this study greatly improved such cellular changes and the level of blood sugar level was corrected. Also, improve dyslipidemia present in diabetic rats. The results showed that the activity of the mixture was better when compared with Nigella, Foenugreek or Termis seeds alone.

Conclusions: The water extract of the mixture is the most powerful in amelioration hyperglycemia and most of all damage effects of Alloxan on hematological parameters and lipid profile. Also, it can control most of the metabolic risk factors of CAD in diabetic rats. So it is advised to use the plant mixture as an antidiabetic agent rather than the use of each plant separately. Repeating such study with the use of variable doses may be helpful in better evaluation for the required dose.
\end{abstract}

\section{Key words: Alloxan - Diabetes - Antidiabetic plants - Pancreas - coronary artery disease}

\section{Introduction}

Coronary heart disease (CHD) has been a global problem since long. It prevails in high class society to low class society and affects all ages specially the middle age group. It is the cause of 25-30 percent of deaths in most industrialized countries. ${ }^{(1)}$

Diabetes mellitus (DM) is possibly the world's fastest growing metabolic disease. (2) $\mathrm{CHD}$ is a major complication of diabetes and the leading cause of early death among people with diabetes. About 65 percent of people with diabetes die from heart disease and stroke. Adults with diabetes are two to four times more likely to have heart disease or suffer a stroke than people without diabetes. High blood glucose in adults with diabetes increases the risk for heart attack, stroke, angina, and coronary artery disease. (3) People with type 2 diabetes also have high rates of high blood pressure, lipid problems, and obesity, which contribute to their high rates of CVD. Smoking doubles the risk of CVD in people with diabetes. ${ }^{(4)}$ 
The United Kingdom Prospective Diabetes Study, (5) and other clinical trials have demonstrated the following benefits of optimal control of the of diabetes: Intensive glucose control reduces the risk of any CHD event by 42 percent and the risk of heart attack, stroke, or death from cardiovascular diseases (CVD) by 57 percent. In general, every percentage point drop in hemoglobin $\mathrm{A} 1_{\mathrm{C}}\left(\mathrm{A} 1_{\mathrm{C}}\right)$ blood test results reduces the risk of diabetes, kidney, eye, and nerve disease by 40 percent. Blood pressure control reduces the risk of CVD among persons with diabetes by 33 percent to 50 percent, and the risk of diabetic kidney, eye, and nerve disease by approximately 33 percent. In general, for every $10 \mathrm{~mm} \mathrm{Hg}$ reduction in systolic blood pressure, the risk for any complication related to diabetes is reduced by 12 percent. Improved control of cholesterol or blood lipids (for example, HDL, LDL, and triglycerides) can reduce CVD complications by 20 to 50 percent. ${ }^{(4)}$

Many plants have been investigated for their beneficial use in DM. The active principles present in medicinal plants have been reported to possess pancreatic beta cells re-generation, increase insulin secretion, enhance glucose uptake by adipose or muscle tissues and inhibit glucose absorption from intestine and glucose production from liver, and antagonize the problem of insulin resistance. (6) Traditional remedies which are often free from side effects are still in use by some diabetic patients in developing countries, and may therefore; present new avenues in the search for alternative hypoglycemic drugs.

Literature survey revealed that Nigella sativa oil lowered blood glucose concentration in diabetic rats and the hypoglycemic effect of Nigella sativa may be mediated by extra pancreatic actions rather than by stimulated insulin release. ${ }^{(7,8)}$ Oral administration of ethanolic extract of Nigella sativa seeds to streptozotocin induced diabetic rats for 30 days reduced the elevated levels of blood glucose and improved altered levels of lipid peroxidation products and because of its antioxidant effects, its administration may be useful in controlling the diabetic complications. ${ }^{(9}$, 10) Foenugreek (Trigonella foenum-gracaeum) may increase plasma insulin level in vivo. ${ }^{(11,1213)}$ Similarly, various hypotheses about the mechanism of the hypoglycemic activity of
Fenugreek have been postulated, including delayed gastric emptying and an agonist effect on insulin receptors. ${ }^{(14)}$ The major free amino acid 4 - hydroxyisoleucine constituent of Foenugreek stimulates insulin secretion from perfuse pancreas in vitro. ${ }^{(15)}$

Termis seeds (Lupine) are a medicinal plant with potential value in the management of diabetes with antihyperglycemic activity present in extracts of the whole seed. In white mice, extracts of seeds of the white lupine [Lupinus albus (L. Termis)] were associated with increased tolerance to an oral glucose admenistration. (16) Despite considerable progress in the treatment of diabetes by oral hypoglycemic agents, search for newer drugs continues because the existing synthetic drugs have several limitations. Alternatives are clearly needed because of the inability of current therapies to control, high cost and poor availability of current therapies for many rural populations, particularly in developing countries. ${ }^{(17)}$ A scientific investigation of traditional herbal remedies for diabetes mellitus may be valuable and leads to development of an alternative drugs and therapeutic strategies.

This study was designed to examine the effects of a water mixture extract of Nigella sativa, Foenugreek and Termis and of each of these plants alone on plasma glucose, lipid profile in diabetic rats as well as the possible effects of these plants on the pancreatic cells types and numbers.

\section{Material and Methods}

The experimental and feeding protocols of the animals used in this study was approved and performed according to the guidelines of Animal House and Ethical Standards of College of Medicine, Taif University, KSA.

\section{Plant material}

The dried seeds of Nigella sativa, Foenugreek and Termis purchased from a local market in Al-Taif, KSA in Jan., 2012.

\section{Preparation of plant extract}

The dried powdered seeds of Nigella sativa, Foenugreek and Termis and a mixture of equal ratio of the powdered seeds were separately powdered and extracted with distilled water by decoction method followed by filtration. ${ }^{(9)}$ 


\section{Animal material}

One hundred fifty adult male albino rats 10-12 weeks age and with body weight ranging between 180-200 gm were used in the current work. Animals that used in the experiments were obtained from the Laboratory Animal Unit, King Fahd Medical Research Centre, King Abdulaziz University, Jeddah. All experiments were taken place at the research laboratories, College of Medicine, Taif University. Animals were housed in clean rodent cages, in a room at relative humidity not less than $30 \%$ and not exceeding $70 \%$, at room temperature $22{ }^{\circ} \mathrm{C}-30{ }^{\circ} \mathrm{C}$, with artificial lighting with a sequence being 12 hours light and 12 hours dark. Animals were fed on conventional laboratory animal diet for rats with an unlimited supply of drinking water. Animals were randomly selected, marked to permit group identification. All animal procedures were performed according to the Guide for the Care and Use of Laboratory Animals of the National Institute of Health as well as the guidelines of the Animal Welfare Act.

Induction of DM was done by giving intrapretonial (ip) injection of freshly prepared Alloxan solution $120 \mathrm{mg} / \mathrm{kg}$ (powder from BDH chemical LTD, England), dissolved in acetate buffer ( $\mathrm{pH}$ 5.5) prepared immediately before use to overnight fasting rats. 48 hours later, blood glucose level was determined by Glucometer for all animals (after oral administration of glucose to fasting rats). Rats with blood glucose level ranging from 180 to 250 were considered diabetic.

\section{Drug Administration}

Aqueous extracts of Nigella sativa, Foenugreek, Termis seeds or a mixture of equal ratio of the powdered seeds, were given orally to male albino diabetic rats in a dose $100 \mathrm{mg} / \mathrm{kg}$ body weight.

The experiment was carried out on six groups; each group contains 25 rats as following:

Group one (Control group): normal rats were given SC saline solution $(0.01 \mathrm{ml} / 100$ gm body weight).

The remaining one hundred diabetic rats were classified as following:

Group two: was considered a diabetic group without receiving any treatment.

Group three: were treated with the aqueous extract of the mixture of equal ratio of the seeds under investigation (100 mg / kg of body weight).
Group four: were treated with the aqueous extract of Nigella sativa seeds $(100 \mathrm{mg} / \mathrm{kg}$ of body weight).

Group fife: were treated with the aqueous extract of Fenugreek seeds (100 mg / kg of body weight).

Group six: were treated with the aqueous extract of Termis seeds (100 mg / kg of body weight).

After 4 weeks, all animals fasted overnight, and then weighted, blood samples were obtained and then rats sacrificed. Blood samples centrifuged at $4000 \mathrm{xg}$ for $10 \mathrm{~min}$ at $4^{\circ} \mathrm{C}$ and supernatant kept at $-70^{\circ} \mathrm{C}$ for further biochemical measurements.

\section{Biochemical assays:}

Biochemical studies were done to assess the following biochemical parameters: serum glucose level, serum insulin level, serum total lipid concentration, serum triglyceride, and serum cholesterol level. Blood indices RBCs, WBCs, haematocrite $(\mathrm{Hct})$ and hemoglobin $(\mathrm{Hb})$ were also assessed.

\section{Histological studies:}

The animals were killed by decapitation. The samples of pancreas were obtained and fixed in $10 \%$ neutral buffered formal saline at $\mathrm{pH} 7.0$ for 5 days. Dehydrated in ascending grades of alcohol and cleared in Benzol. Samples from each group were embedded in paraffin with a melting point between $55{ }^{\circ} \mathrm{C}$ and $56{ }^{\circ} \mathrm{C}$ for 4 hours and then paraffin blocks were prepared. Paraffin sections were made at $5 \mu \mathrm{m}$ and stained with Hematoxylin \& Eosin for demonstrating any histological changes. Modified Aldehyde Fuchsin (18) for detecting different cells of islets of Langerhans was done. Then sections were examined under the Microscope. Image analysis system was used for determination alpha, beta and delta cells number and diameters in the islet of Langerhans.

\section{Statistical analysis:}

Data were analyzed using SPSS version 20. Normality of distribution was computed by Kolmogrov smirnov test and W Shapiro-Wilk's test. $X^{2}$ and Fisher exact tests were applied to observe association between qualitative variables. Quantitative variables were expressed in means \pm SDs. The comparison of quantitative data was performed by independent t-test or Mann Whitney test according to normality of distribution for independent variables consisting of two groups and by ANOVA and Kruskal Wallis test according to normality of distribution 
for independent variables consisting of more than two groups. Post Hoc Turkey test was applied to observe which groups mean differs. Statistical significance was set at 0.05 levels. ${ }^{(19)} \mathrm{A}$ p-value of $<0.05$ was considered as statistically significant.

\section{RESULTS}

As shown in tables (1\&2), after induction of DM by Alloxan, the serum glucose level raised to about $266 \mathrm{mg} / \mathrm{dl}(\mathrm{p}=0.008)$ and serum insulin level fallen to about $21 \mathrm{U} / \mathrm{L}(\mathrm{p}=0.008)$ with significant increase levels of serum cholesterol and LDL with non significant decrease in HDL level in diabetic rats. After treatment, the results of glucose concentrations $(\mathrm{mg} / \mathrm{dl})$ for groups of rats treated by mixture of herbs, Nigella, Foenugreek and Termis seeds (after the $4{ }^{\text {th }}$ week of treatment) with mean \pm S.E. were $127 \pm 1.58$, $131.2 \pm 4.43,131.2 \pm 1.92$ and $134.8 \pm 0.83$ respectively. The glucose lowering effect occur in all treated groups with more marked decrease in the group of rats treated by mixture of herbs $(p<0.001)$. Also, insulin was statistically increased in all treated groups of rats as compared with non-treated group $(\mathrm{p}<0.001)$. The rise was more marked in rats treated by mixture of herbs $(p<0.001)$. The levels of serum cholesterol and LDL were significantly decreased when compared with diabetic group $(\mathrm{p}<0.001)$. The lowering effect was more in Nigella and Fenugreek groups $(\mathrm{p}<0.001)$. HDL showed nonsignificant increase among treated groups.

Table (3\& 4) illustrates the effects of induction of DM by Alloxan on blood indices. RBCs number, $\mathrm{HCT}$ and $\mathrm{Hb}$ levels were significantly decreased in diabetic compared to control groups with no effect on WBCs number. There is statistically significant increased RBCs, $\mathrm{HCT}$, and $\mathrm{Hb}$ in all treated groups as compared to diabetic group $(p<0.001)$. The effect was significantly more marked in mixture treated group $(\mathrm{p}<0.001)$ except for Nigella treated group where there is nonsignificant change in RBCs, HCT, and $\mathrm{Hb}$. No significant differences were found among all studied groups regarding the number of WBCs. $(\mathrm{p}<0.973)$

Histological study of pancreas in treated and nontreated groups of rats (tables 5, 6 and figures 1, 2, and 3) was shown induction of diabetes by Alloxan in rats had no effect on alpha and delta cells (number, cell and nuclear diameters).
However, significant decrease in beta cells number and increase in beta cells diameter as well as nuclear diameters was found in diabetic group as compared to control group ( $\mathrm{P}<0.001)$. All treated groups showed significant increase in beta cells number and decrease in beta cells diameter as well as nuclear diameters as compared to non-treated groups $(\mathrm{p}<0.001)$. However, the effect on beta cell number was more marked in rats treated by a mixture of plants $(p<0.001)$. Other effects on beta cell diameter and nuclear diameter showed no significant differences among all treated groups.

\section{Discussion:}

$\mathrm{DM}$ is one of the most diseases in the modern soc iety and represents not only important medical but also social problem. In industrialized countries, the prevalence of DM is $2 \%$ $4 \%$ in the general population, and up to $10 \%$ in the age group over 65 , its incidence showing an increase in tendency. According to estimates of World Health Organization (WHO) experts, significant increase in DM incidence is expected among persons aged over 25 . So, the number of patients of this age group will increase from 135 million to 300 million during the 1995 - 2025 periods. It has been clearly shown that there are 2 to 2.5 non diagnosed patients per each registered DM patient, and this takes place at the expense of subjects with type $2 \mathrm{DM}$. On the other hand, cardiovascular diseases presently are the maincause of death in diabetic patients. According to WHO data, more than $75 \%$ of patients with type $2 \mathrm{DM}$ die due to vascular accidents. ${ }^{(20)}$ Increased level of blood cholesterol, low density lipoprotein, triglycerides, smoking and raised blood pressure is established as major risk factors for coronary heart disease. Prevention of myocardial ischemia has been therapeutic targets for a long time. ${ }^{(21,22)}$

This study is a step to evaluate the effects of some water extracts of medicinal plants as antidiabetic agents individually and as a mixture. Severe hyperglycemia in diabetic rats recorded in the present work can be considered as a direct reflex to the marked hypoinsulinemia caused by the selective destructive cytotoxic effect of Alloxan on the $\beta$-cells of the pancreas which has a direct effect on their membrane permeability by causing failure of ionic pumps and increased cells size. ${ }^{(23,24)}$ Our results revealed glucose lowering effect in all treated groups after the $4^{\text {th }}$ week of 
treatment which is more marked in the group treated by mixture of herbs $(\mathrm{p}<0.001)$. Also, insulin was statistically increased in all treated groups as compared with diabetic group $(\mathrm{p}<$ $0.001)$. The rise was more marked in rats treated by mixture of herbs $(\mathrm{p}<0.001)$.

Abdel Moneim et al. (25) reported that the hypoglycemic effect of Nigella sativa may be attributed to an increase in the Islet numbers and to its effect on the time-course of glucose reabsorption from the intestine. On the other hand, the treated group showed significant increase in beta cell number and decrease in their diameters as well a nuclear diameter was found in all treated groups. These plants may have a stimulatory effect on the division of $\beta$-cells, block the diabetogenic action of Alloxan and restore insulin production. ${ }^{(26)}$ The treatment with Nigella sativa induced islet cells regeneration with increased number of $\beta$-cells. (25) Augusti and Sheela, 1996, (27) mentioned that some plants exert their effect on beta cells through both protection of the already present beta cells due to their antioxidant effect and through stimulation of the beta cells to release insulin.

Marles et al. ${ }^{(10)}$ suggested that, the hypoglycemic effect of some medicinal plants could be attributed to factors other than stimulation of insulin release only, e.g. their effect on the number and /or affinity of insulin receptors on target cells and the post-receptors of these cells. An increase in concentration of total cholesterol and LDL cholesterol, and a decrease in HDL cholesterol are associated with raised risk of myocardial infarction. (28) There are a growing evidences from epidemiologic, clinical and laboratory data indicating that elevated triglyceride levels are an independent risk factor for cardiovascular disease. Hyperlipidemic patients at a risk for cardiovascular disease often develop a lipoprotein profile characterized by elevated triglyceride, dense LDL, and low HDL cholesterol which causes myocardial membrane damage. ${ }^{(29)}$

Our results revealed that the levels of total cholesterol and LDL were significantly decreased in treated groups than non-treated group $(\mathrm{p}<$ $0.001)$. The lowering effect was more in Nigella for total lipids $(p<0.001)$, and in Fenugreek for cholesterol and LDL ( $\mathrm{p}<0.001)$. This may attributed to their stimulation to the most aspects of carbohydrate metabolism, including rapid uptake of glucose by the cells, enhanced gluconeogenesis, increased rate of absorption from the gastrointestinal tract and even increased insulin secretion with its resultant secondary effects on carbohydrate metabolism. (28) The lowering effect was more in Nigella for total lipids ( $\mathrm{p}<0.001)$, and in Fenugreek for cholesterol and LDL $(p<0.001)$. Zahida et al. ${ }^{(19)}$ stated that the Nigella sativa is effective to change the lipid profile significantly. Akash et al. ${ }^{(29)}$ mentioned that some medicinal herbs may have antioxidant effects especially Nigella sativa. Ghazi Mahmood et al. (30) stated that, Nigella sativa is more effective than Gemfibrozil in hyperlipidemia and it can be used as add on drug therapy in patients of metabolic syndrome with poor glycemic control. The most important action of Nigella sativa that may be responsible for its beneficial effect in metabolic syndrome is its insulin sensitizing action.

Our data illustrate the effects of induction of DM by Alloxan on blood indices where RBCs number, $\mathrm{Hct}$ and $\mathrm{Hb}$ levels were significantly decreased in diabetic compared to control groups. These parameters statistically increased in all treated groups as compared to diabetic group $(p \leq 0.001)$. The effect was significantly more marked in mixture treated group $(\mathrm{p}<0.001)$ except for Nigella treated group where there is nonsignificant decrease in Hct and Hb. This anemia could be attributed, to destruction of RBCs and reduced rate of red blood cells released from the bone marrow to blood. Several investigators attributed this anemia to the increase in lipid peroxidation of the erythrocyte cell membrane by the destructive effect of Alloxan. ${ }^{(32)}$ Finally, the water extract of the mixture is the most powerful in amelioration hyperglycemia and all damage effects of Alloxan on the hematological parameters, and lipid profile.

\section{Conclusion:}

The studied herbs in this work and water extract of the mixture of these plants appeared to be useful agents in reducing the hyperglycemia by increasing insulin level and regenerating beta cells of the pancreas. However, a mixture of these plants proved to be more effective than each of them without added side effects. The water extract of the mixture is the most powerful in amelioration of all damage effects of Alloxan on hematological parameters, and lipid profile. Also, it can control most of metabolic risk factors of CAD in diabetic rats. So it is advised to use the 
plant mixture as an antidiabetic agent rather than the use of each plant separately. More studies on these plants are advised be done with different doses and for different periods before recommending their use on a wide scale.

Acknowledgment: The authors acknowledge the Scientific Research Deanship, Taif University, KSA for the financial support of this work

\section{References:}

1. Park K. (2004): Parks text book of preventive and social medicine. Jabalpur India: Banarasi Das Bhanot, 24 ${ }^{\text {th }}$ ed. Vol., 1272 - 73.

2. National Institute of Diabetes and Digestive and Kidney Diseases. National diabetes statistics fact sheet: general information and national estimates on diabetes in the United States, 2005. Bethesda, MD: U.S. Department of Health and Human Services, National Institutes of Health; 2005.

3. Adler AI, Stratton IM, Neil HA, et al. (2000): Association of systolic blood pressure with macrovascular and microvascular complications of type 2 diabetes (UKPDS 36): prospective observational study. BMJ., 321 (7258):412-419.

4. Hongxiang $H$ and Vay Liang W. (2009): Hypoglycemic herbs and their action mechanisms. Chin Med., 4: 11-14.

5. El-Dakhakhny M, Mady N, Lembert N, Ammon HP. (2002): The hypoglycemic effect of Nigella sativa oil is mediated by extrapancreatic actions. Planta Med., 68(5):465-6.

6. Meral, I, Yener, Z, Kahraman, T and Mert, N. (2001): Effect of Nigella sativa on glucose concentration, lipid peroxidation, anti-oxidant defense system and liver damage in experimentally induced diabetic rabbits. J. Vet. Med. A. Physiol. Pathol. Clin. Med., 48 (10)593-9.

7. Fararh K, Atoji Y, Shimizu Y, Shiina T, Nikami H, Takewaki T. (2004): Mechanisms of the hypoglycaemic and immunopotentiating effects of Nigella sativa L. oil in streptozotocin-induced diabetic hamsters. Res Vet Sci., 77(2):123-9.

8. Kaleem M, Kirmani D, Asif M, and Ahmed Q, Bano B. (2006): Biochemical effects of Nigella sativa L seeds in diabetic rats. Indian J Exp Biol., 44(9):745-8.

9. Alarcon-Aguilara F, Roman R, Perez S, Aguilar A, Contreras C, Flores J. (1998): Study of the antihyperglycemic effect of plants used as antidiabetics. J Ethnopharmacol., 61(2):101-10.

10. Khatir AMM, Ding $X$ and Fang T. (1999): Hypoglycemic effect of fenugreek gum on normal and alloxan diabetic rats. Journal of Wuxi, 18: 1620 .
11. Kavishankar G, Lakshmidevi N, Mahadeva M, Prakash H. (2011): Diabetes and medicinal plantsA review. Int J Pharm Biomed Sci., 2(3): 65-80

12. Wadkar K, Magdum C, Patil S, Naikwade N. (2008): Antidiabetic potential and Indian medicinal plants. J Herbal Med and Toxicol., 2: 45-50.

13. Al-Habbori M and Raman A. (1998). Antidiabetic and hypocholesterolemic effects of fenugreek. Phytotherapy Research, 12: 233-42.

14. Knecht K, Nguyen H, Auker A, Kinder D. (2006). Effects of extracts of lupine seed on blood glucose levels in glucose resistant mice: antihyperglycemic effects of Lupinus albus (white lupine, Egypt) and Lupinus caudatus. J Herb Pharmacother., 6(34):89-104.

15. Marles, R and Farnsworth N. (1995): Antidiabetic plants and their active constituents. Phytomedicine, 2: 137-89.

16. Halami N. (1952): Differentiation of the two types of basophiles in an adenohypophysis of the rat and the mouse. Stain Technology, 27: 61.

17. Sokal R and Rahif F. (1981): The principles and practical of statistic in Biological Research. $2^{\text {nd }}$ ed. free man, W.H. Company, San Frrancisco.

18. A. Efimov L, Sokolova M, Sokolov N. (2001): Diabetes mellitus and coronary heart disease. Diabetologia Croatica, 30:4.

19.Zahida T, Zeshan S, Nisar A and Mushtaq H. (2011):The Effects of Nigella sativa (Kalonji) on Lipid Profile in Patients with Stable Coronary Artery Disease in Multan, Pakistan. Pakistan Journal of Nutrition, 10 (2): 162-67.

20. Murugesan M, Ragunath M, Prabu T, Nadanasabapathi S, Sakthivel M, Manju V. (2012): Protective role of black cumin (Nigella sativa) on isoproterenol induced myocardial infarction in rats. Int J Pharmacol and Clin Sci ., 1:45-53.

21. Ganong W. (2003): Review of medical physiology, $23^{\text {rd }}$ ed., Lange med. Public, Chapter. 19:306-26.

22. Helal E, Hasan M, Mustafa A and Al-Kamel A. (2003): Effect of Aloe vera extract on some physiological parameters in diabetic albino rats. The Egyptian Journal of Hospital Medicine, 12: 5361.

23. Abdel-Moneim A, El-Feki M and Salah E. (1999): Effect of Nigella Sativa, fish oil and gliclazide on Alloxan-diabetic rats. Biochemical and histopathological studies. J. Egypt. Ger. Sc. Zool., 23 (A): 237-65.

24. Ahmad N, Mohammad N, Rahat K, SHAHZAD F. (2012): Therapeutic effect of Nigella Sattiva in patients of poor glycaemic control. Asian J. Pharm. Clin. Res., 5(3): 224-8.

25. Augusti K. and Sheela, G. (1996): Theory and practice of histological techniques. $4^{\text {th }}$ edition. Churchill Living. Edinburgh and London.Pp.123.

26. Milionis HJ, Daskalopoulou SS, Elisaf M, Mikhailidis DP. (2005): The predictive value of 
lipid markers in vascular disease. Curr Pharmac Design, 11:2209-24.

27. Mediene-Benchekor, Brousseau T, Richard F, Benhamamouch S, Amouyel P. (2001): Blood lipid concentrations and risk of myocardial infarction. The Lancet, 358:1064-5.

28. Duke JA. (2002): Hand book of medicinal Herbs. $2^{\text {nd }}$ ed. United States of America, Pp.: 15-51.

29. Akash M, Rehman1 F, Sethi A, Abrar M, Irshad A, Abid A and Murtaza G. (2011): Alternate therapy of Type 2 diabetes mellitus (T2DM) with Nigella (Ranunculaceae). Journal of Medicinal Plants Research. , 5(31):6885-89.

30. Ghazi Mahmood, Aruna Bashir, Shah Murad, Javed Asghar, Shaheena Asif, Abdul Majeed Ch,
Muhammad Aslam (2012): Comparison of lipid lowering effects of Nigella Sativa and Gemfibrozil. International Journal of Pharmaceutical Research \& Development. 3(12): 6-10.

31. Ebihara K, Ogawa Y and Masuzaki H. (2001): Transgenic over expression of liptin rescues insulin resistance and diabetes in a mouse model of Lipoatrophic diabetes. Diabetes, 50 (6): 1140.

32. Azeez O, Oyagbemi A, Oyeyemi M, and Odetola A (2010): Ameliorative effects of Cnidoscolus aconitifolius on Alloxan toxicity in Wistar rats. Afr Health Sci. September; 10(3): 283-91.

Table (1) Comparison between control and diabetic groups as regard metabolic profile

\begin{tabular}{|c|c|c|}
\hline & Control & Diabetic \\
\hline Blood glucose & $136.8 \pm 1.9$ & $266.4 \pm 0.89 *$ \\
\hline Serum insulin & $41.2 \pm 0.83$ & $20.2 \pm 1.4 *$ \\
\hline Total lipids & $4.5 \pm 0.33$ & $13.7 \pm 0.47^{*}$ \\
\hline Cholesterol & $143.4 \pm 2.2$ & $222.1 \pm 1.1^{*}$ \\
\hline LDL & $69.3 \pm 2.8$ & $125.9 \pm 2.05 *$ \\
\hline HDL & $47.2 \pm 0.75$ & $44.1 \pm 1.4^{*}$ \\
\hline
\end{tabular}

Table (2) Comparison between diabetic groups as regard metabolic profile after treatment

\begin{tabular}{|l|c|c|c|c|c|}
\hline & $\begin{array}{c}\text { Diabetic } \\
\text { untreated } \\
\text { rats }\end{array}$ & $\begin{array}{c}\text { Mixture } \\
\text { treated group }\end{array}$ & $\begin{array}{c}\text { Nigella treated } \\
\text { group }\end{array}$ & $\begin{array}{c}\text { Foenugreek } \\
\text { treated group }\end{array}$ & $\begin{array}{c}\text { Termis } \\
\text { treated group }\end{array}$ \\
\hline Blood glucose & $266.4 \pm 0.89$ & $127 \pm 1.58^{* *}$ & $131.2 \pm 4.43^{*}$ & $131.2 \pm 1.92^{*}$ & $134.8 \pm 0.8^{*}$ \\
\hline Serum insulin & $20.2 \pm 1.4$ & $45.2 \pm 3.3^{*}$ & $32.4 \pm 3.2^{*}$ & $38.4 \pm 1.5^{*}$ & $34.6 \pm 2.3^{*}$ \\
\hline Cholesterol & $222.1 \pm 1.1$ & $141.4 \pm 0.79^{*}$ & $191.1 \pm 2.7^{* *}$ & $140.6 \pm 1.3^{* *}$ & $190.5 \pm 2.7^{*}$ \\
\hline LDL & $125.9 \pm 2.05$ & $68 \pm 0.92^{*}$ & $114.8 \pm 1.6^{* *}$ & $67.8 \pm 2.05^{* *}$ & $72.2 \pm 1.5^{*}$ \\
\hline HDL & $44.1 \pm 1.4$ & $45.8 \pm 0.93$ & $45.3 \pm 2.4$ & $45.2 \pm 3$ & $45 \pm 2.05$ \\
\hline
\end{tabular}

Table (3) Comparison between control and diabetic groups as regard CBC parameters

\begin{tabular}{|l|c|c|}
\hline & Control Group & Diabetic Group \\
\hline RBCs & $7.5 \pm 0.27$ & $5.5 \pm 0.38^{*}$ \\
\hline WBCs & $12.4 \pm 1.2$ & $12.3 \pm 0.73$ \\
\hline HCT & $44.2 \pm 1.5$ & $40.1 \pm 2.3$ \\
\hline Hb & $14.7 \pm 0.52$ & $12.6 \pm 0.42^{*}$ \\
\hline
\end{tabular}


Table (4) Comparison between diabetic groups as regard $\mathrm{CBC}$ after treatment

\begin{tabular}{|l|c|c|c|c|c|}
\hline & $\begin{array}{c}\text { Diabetic } \\
\text { untreated } \\
\text { rats }\end{array}$ & $\begin{array}{c}\text { Mixture } \\
\text { treated group }\end{array}$ & $\begin{array}{c}\text { Nigella } \\
\text { treated } \\
\text { group }\end{array}$ & $\begin{array}{c}\text { Foenugreek } \\
\text { treated } \\
\text { group }\end{array}$ & $\begin{array}{c}\text { Termis } \\
\text { treated } \\
\text { group }\end{array}$ \\
\hline RBCs & $5.5 \pm 0.38$ & $7.5 \pm 0.30^{* *}$ & $5.8 \pm 0.44$ & $6.9 \pm 0.14^{*}$ & $6.7 \pm 0.50^{*}$ \\
\hline WBCs & $12.3 \pm 0.73$ & $12.5 \pm 1.30$ & $12.3 \pm 0.63$ & $12.4 \pm 0.55$ & $12.5 \pm 0.54$ \\
\hline HCT & $40.1 \pm 2.3$ & $43.8 \pm 1.20^{* *}$ & $36.8 \pm 2.8$ & $44.2 \pm 1.4 *$ & $44.8 \pm 1.1^{*}$ \\
\hline Hb & $12.6 \pm 0.42$ & $14.6 \pm 0.42^{* *}$ & $11.6 \pm 0.96$ & $13.2 \pm 0.43^{*}$ & $12.4 \pm 0.53^{*}$ \\
\hline
\end{tabular}

Table (5) Comparison between control and diabetic groups as regard different pancreatic cells

\begin{tabular}{|c|c|c|c|}
\hline & & Control Group & Diabetic Group \\
\hline \multirow{3}{*}{ 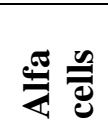 } & Number & $2.83 \pm 0.64$ & $2.43 \pm 1.04$ \\
\hline & Nuclear Diameter & $1.34 \pm 0.43$ & $1.50 \pm 0.42$ \\
\hline & Cell Diameter & $3.03 \pm 0.60$ & $3.48 \pm 0.78$ \\
\hline \multirow{3}{*}{ 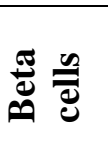 } & Number & $32.66 \pm 13.94$ & $10.80 \pm 5.14 * *$ \\
\hline & Nuclear Diameter & $1.58 \pm 0.35$ & $2.39 \pm 0.48 * *$ \\
\hline & Cell Diameter & $3.25 \pm 0.29$ & $4.49 \pm 0.74 * *$ \\
\hline \multirow{3}{*}{ 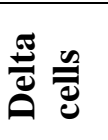 } & Number & $4.3 \pm 1.6$ & $4.40 \pm 1.84$ \\
\hline & Nuclear Diameter & $2.01 \pm 0.47$ & $2.01 \pm 0.56$ \\
\hline & Cell Diameter & $4.45 \pm 1.36$ & $4.33 \pm 0.62$ \\
\hline
\end{tabular}

Table (6) Comparison between diabetic groups as regard different pancreatic cells after treatment

\begin{tabular}{|c|c|c|c|c|c|c|}
\hline & & $\begin{array}{c}\text { Diabetic } \\
\text { untreated } \\
\text { rats }\end{array}$ & $\begin{array}{c}\text { Mixture } \\
\text { treated } \\
\text { group }\end{array}$ & $\begin{array}{l}\text { Nigella } \\
\text { treated } \\
\text { group }\end{array}$ & $\begin{array}{c}\text { Foenugreek } \\
\text { treated } \\
\text { group }\end{array}$ & $\begin{array}{l}\text { Termis } \\
\text { treated } \\
\text { group }\end{array}$ \\
\hline \multirow{3}{*}{ 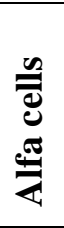 } & Number & $2.43 \pm 1.04$ & $2.40 \pm 0.89$ & $2.93 \pm 1.74$ & $2.93 \pm 1.74$ & $2.80 \pm 1.49$ \\
\hline & $\begin{array}{l}\text { Nuclear } \\
\text { Diameter }\end{array}$ & $1.50 \pm 0.42$ & $1.27 \pm 0.31$ & $1.25 \pm 0.28$ & $1.25 \pm 0.28$ & $1.36 \pm 0.39$ \\
\hline & $\begin{array}{l}\text { Cell } \\
\text { Diameter }\end{array}$ & $3.48 \pm 0.78$ & $2.88 \pm 0.55$ & $2.96 \pm 0.68$ & $2.96 \pm 0.68$ & $3.15 \pm 0.73$ \\
\hline \multirow{3}{*}{ 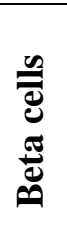 } & Number & $10.80 \pm 5.14$ & $34.12 \pm 16^{* *}$ & $25.90 \pm 13.70 *$ & $25.90 \pm 13.70 *$ & $26 \pm 10.94 *$ \\
\hline & $\begin{array}{l}\text { Nuclear } \\
\text { Diameter }\end{array}$ & $2.39 \pm 0.48^{*}$ & $1.32 \pm 0.17 *$ & $1.31 \pm 0.27 *$ & $1.31 \pm 0.27 *$ & $1.33 \pm 0.21 *$ \\
\hline & $\begin{array}{l}\text { Cell } \\
\text { Diameter }\end{array}$ & $4.49 \pm 0.74$ & $3.02 \pm 0.46^{*}$ & $2.70 \pm 0.38^{*}$ & $2.70 \pm 0.38^{*}$ & $3.06 \pm 0.50 *$ \\
\hline \multirow{3}{*}{ 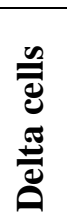 } & Number & $4.40 \pm 1.84$ & $3.40 \pm 1.10$ & $3.46 \pm 0.89$ & $3.43 \pm 1.04$ & $3.40 \pm 1.16$ \\
\hline & $\begin{array}{l}\text { Nuclear } \\
\text { Diameter }\end{array}$ & $2.01 \pm 0.56$ & $1.90 \pm 0.63$ & $1.73 \pm 0.77$ & $1.74 \pm 0.70$ & $1.83 \pm 0.68$ \\
\hline & $\begin{array}{l}\text { Cell } \\
\text { Diameter }\end{array}$ & $4.33 \pm 0.62$ & $3.66 \pm 1.06$ & $3.34 \pm 0.64$ & $3.33 \pm 0.67$ & $3.03 \pm 0.46$ \\
\hline
\end{tabular}




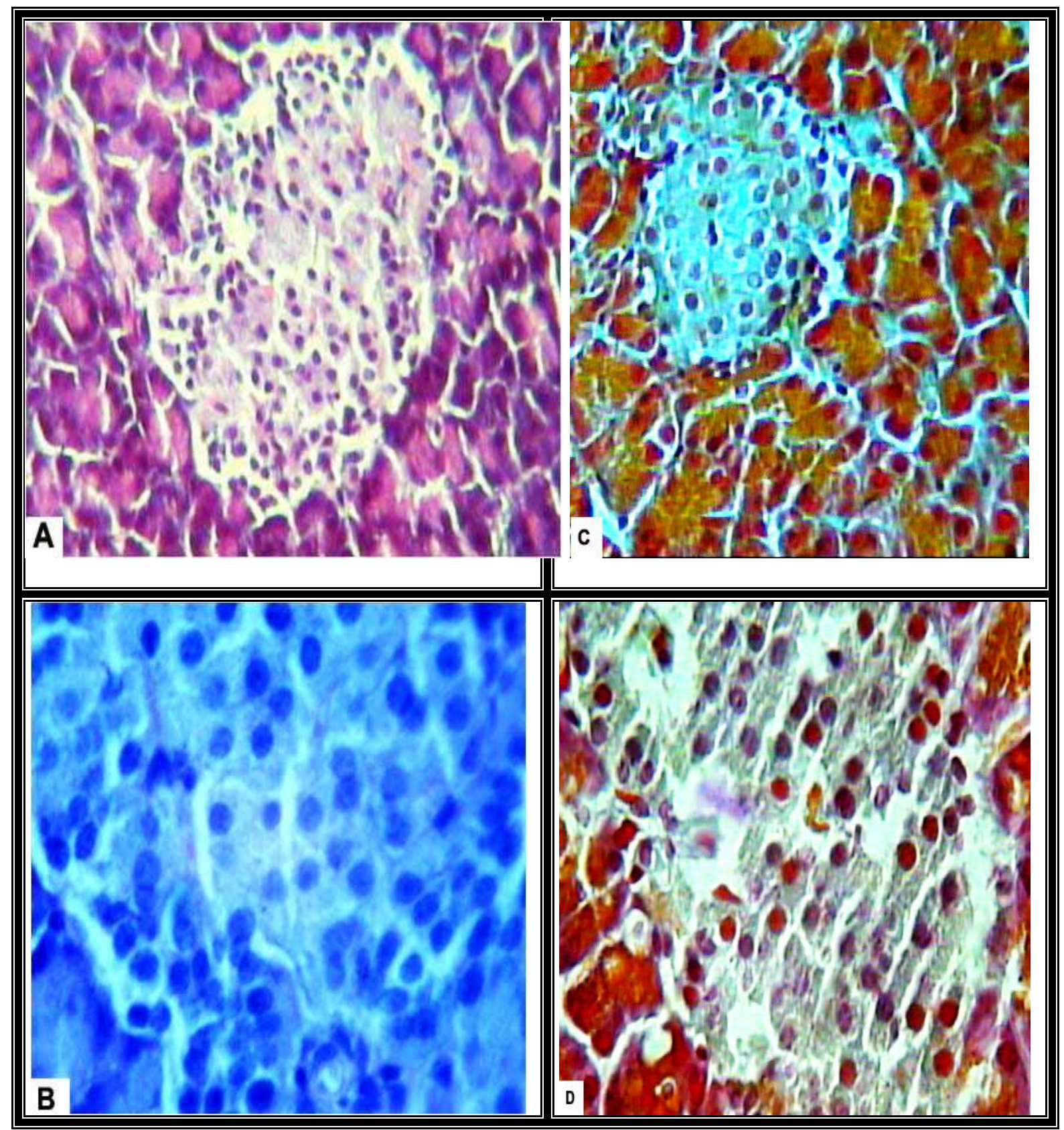

Fig (1): A photomicrograph of a section in the pancreas of control adult male rat showing:

- $\quad$ A\& B: rounded or oval and prominent nuclei within the B-cells, notice the deeply basophilic nuclei of A-cell.

- $\quad(\mathrm{Hx} \& \mathrm{E} \quad$ (A) X400 (B) X 1200).

- C\&D: rounded or oval violet B-cell, oval green D cells and irregular yellow A-cell.

(Modified aldehyde fuchsin (C) X 400 (D) X 1200). 


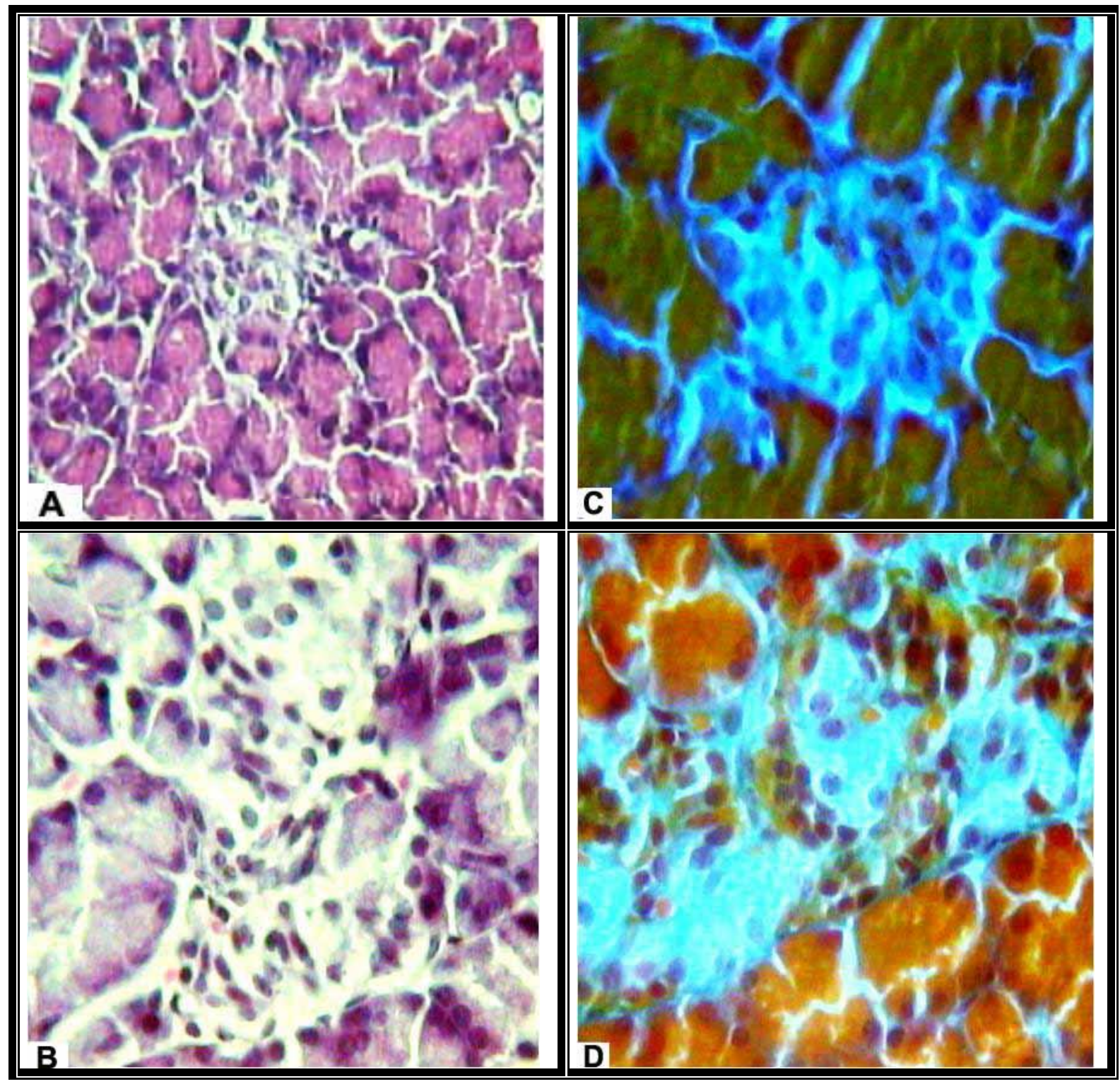

Fig (2): A photomicrograph of a section in the pancreas of a diabetic rat showing:

- $\quad$ A\&B: small sized islet with pale disintegrated nuclei and the intact dark cells at the periphery of the islet with normal structure of the exocrine pancreas. (Hx \& E (A) X400 (B) X 1200).

- $\quad$ C\&D: small sized islet with pale disintegrated nuclei, vacuolated B -cell, deeply green delta cell and faintly stained A-cell. (Modified Aldehyde Fuchsin (C) X 400 (D) X 1200). 


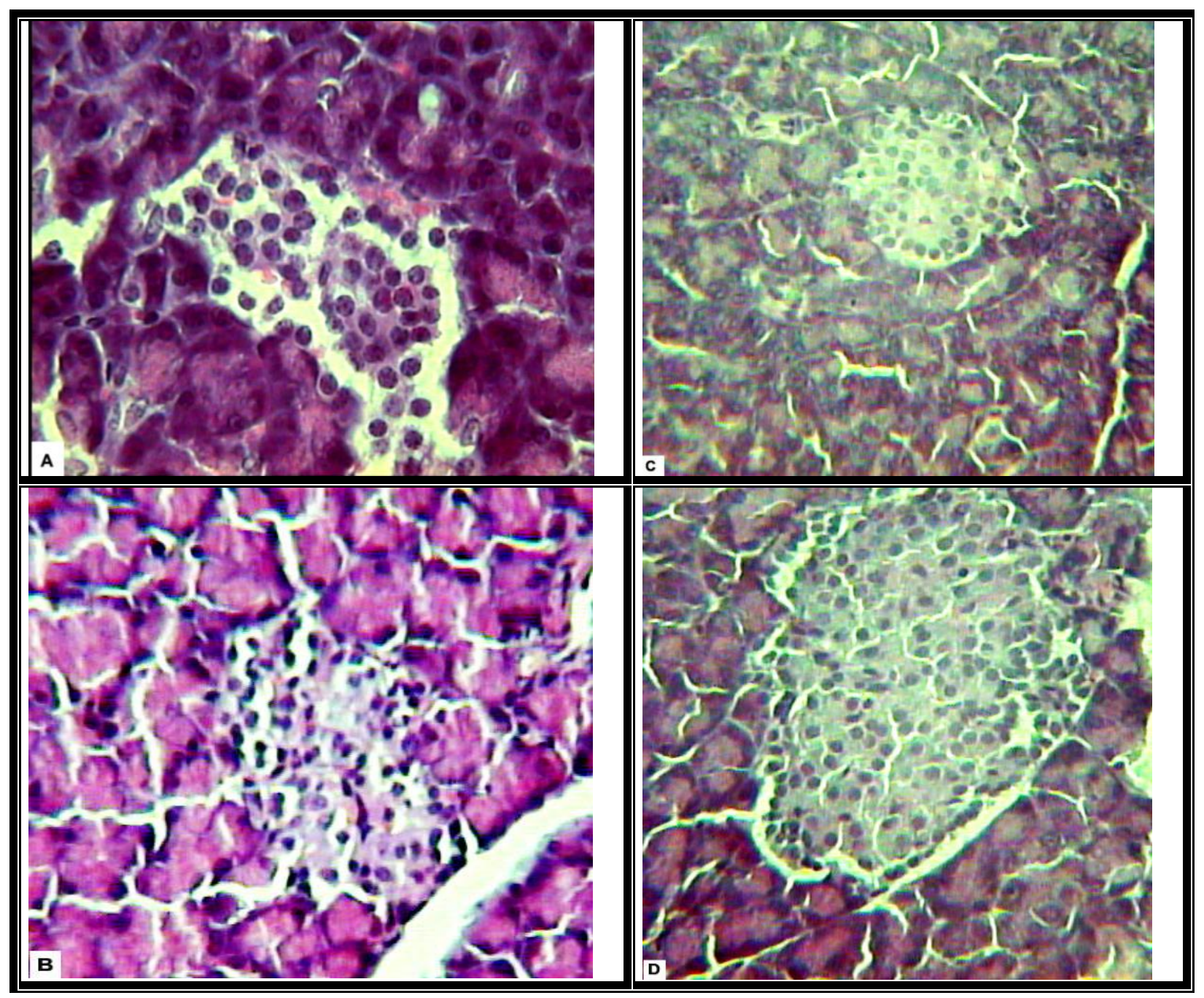

Fig (3): A photomicrograph of a section in the pancreas of a diabetic rat 30 day showing:

A -Section in the pancreas of a diabetic mixture ingested rat showing decreased signs of vacuolation in Bcell with normal islets.

B -Section in the pancreas of an adult male diabetic Nigella Sativa ingested rat illustrating vacuolated Bcell, deeply stained nuclei, and within normal islets.

$\mathrm{C}$ - Section in the pancreas of an adult male diabetic Termis seeds ingested rat showing vacuolated and degenerated B-cell. Small islet having cellularity and poor vascularity.

D -Section in the pancreas of an adult male diabetic Foenugreek ingested rat showing less vacuolated Bcells, and within normal islets. (Hx\& E X 400). 